\title{
PENGARUH TERAPI RELAKSASI ZIKIR TERHADAP PENURUNAN TINGKAT KECEMASAN PADA PENDERITA DISPEPSIA
}

\section{EFFECT OF DHIKR RELAXATION THERAPY TO REDUCE ANXIETY LEVELS IN DYSPEPSIA PATIENTS}

\author{
Citra Y. Perwitaningrum \\ Yayi Suryo Prabandari \\ Rr. Indahria Sulistyarini \\ Fakultas Psikologi dan IImu Sosial Budaya, Universitas Islam Indonesia Yogyakarta \\ Email : citrayuniastri@yahoo.com
}

\begin{abstract}
This research aimed to seek the effect of Dhikr relaxation therapy to reduce anxiety levels in dyspepsia patients. Subjects in this research were dyspepsia patients who have high and moderate levels of anxiety. Subjects in this research were eight subjects which divided into two groups; four subjects in the experimental group four subjects in the control group. The data was obtained by utilizing Hamilton Anxiety Rating Scale (HARS). This research wasa non-randomized pretest pascatest control design. Analysis to examine this hypothesis using the Mann Whitney $U$. The result showed that the group was given Dhikr relaxation therapy these anxiety were lower than the group wasn't given Dhikr relaxation therapy.
\end{abstract}

Keyword: Dhikr relaxation therapy, anxiety, dyspepsia

\begin{abstract}
ABSTRAK
Penelitian ini bertujuan untuk mengungkapkan pengaruh terapi relaksasi zikir terhadap penurunan tingkat kecemasan pada penderita dispepsia. Subjek dalam penelitian ini adalah pasien dispepsia yang memiliki tingkat kecemasan dalam kategori sedang sampai dengan berat. Subjek penelitian ini berjumlah 8 orang yang terbagi dalam 2 kelompok, yaitu 4 orang kelompok eksperimen dan 4 orang kelompok kontrol. Pengumpulan data dilakukan dengan menggunakan skala Hamilton Anxiety Rating Scale (HARS). Penelitian ini merupakan penelitian non-randomized pretest posttest control design. Skala kecemasan yang digunakan adalah skala HARS yang sudah ada dengan reliabilitas dan validitas sebesar 0,93 dan 0,97. Hipotesis dalam penelitian ini diuji dengan Mann Whitney $U$. Hasil penelitian menunjukkan kelompok yang diberi terapi relaksasi zikir kecemasannya lebih rendah dari pada kelompok yang tidak diberi terapi relaksasi zikir.
\end{abstract}

Kata kunci : terapi relaksasi zikir, kecemasan, dispepsia.

Gangguan psikofisiologi merupa- berbagai keluhan fisik yang jelas, tetapi kan keluhan yang banyak ditemukan di tidak jarang lebih banyak keluhan fisik Puskesmas. Penderita datang dengan yang dilatarbelakangi oleh kondisi psi- 
kologis. Penderita mengeluhkan adanya gangguan pada organ bagian dalam. Salah satunya adalah keluhan pada bagian pencernaan, meliputi perut mual, sakit perut, kembung atau biasa disebut dispepsia.

Data pasien rawat jalan tahun 2010, di rumah sakit seluruh Indonesia menyebutkan bahwa dispepsia berada pada urutan ke 6 dari 10 penyakit terbanyak di rumah sakit di seluruh Indonesia dengan data jumlah kunjungan sebanyak 163.428. Data pasien rawat inap tahun 2010 tidak jauh berbeda dengan pasien rawat jalan, dispepsia masuk pada urutan ke 5 dari 10 penyakit terbanyak di rumah sakit di Indonesia (Departemen Kesehatan RI, 2011).

Sebuah hubungan sebab akibat antara gangguan kejiwaan dan gangguan pencernaan fungsional telah menjadi kontroversi baru-baru ini. Sebuah bukti yang menunjukkan hubungan ini datang dari sebuah penelitian besar metaanalysis yang hasilnya menunjukkan bahwa dispepsia fungsional dan irritable bowel syndrome (IBS) berhubungan erat dengan kecemasan dan depresi. Studi yang dilakukan Henningsen, Zimmermann, dan Sattel (2003) menunjukkan bahwa tidak terdapat perbedaan tingkat depresi antara pasien yang mendapat pengobatan medis dengan yang tidak, sedangkan tingkat kecemasan sedikit lebih tinggi pada pasien yang mendapat pengobatan medis (Kusuma, 2011). Sebuah studi berbasis populasi Swedia baru-baru ini menemukan bahwa kecemasan tanpa depresi terkait dengan uninvestigated dispepsia dan dispepsia fungsional(Aro dkk, 2009).

Sebuah penelitian yang dilaksanakan oleh Arinton, Pugud, dan Soewignjo (2005) di Klinik Penyakit Dalam di RSUD Prof. Dr. Margono Soekarjo Purwokerto dari tanggal 2 Januari sampai 31 Desember 2005 terhadap pasien yang dapat berbahasa Indonesia dengan keluhan dispepsia didapatkan angka prevalensi cukup besar, yaitu mencapai 60\% (Kusuma, 2011). Hasil penelitian lain mengemukakan bahwa kecemasan secara signifikan berpengaruh terhadap pasien dengan dispepsia fungsional. Semakin tinggi tingkat kecemasan seseorang, semakin tinggi pula tingkat keparahan dispepsia fungsionalnya, dan hal ini berlaku sama baik untuk laki-laki maupun perempuan (Kusuma, 2011)

Hasil studi yang dijabarkan di atas memiliki kesamaan dengan hasil wawancara dengan psikolog yang bekerja di salah satu puskesmas di Kabupaten Sleman yang mendapatkan bahwa pasien yang datang ke poli psikologi atas rujukan dokter dari poli umum biasanya 
telah didiagnosis dispepsia. Tidak hanya penderita dengan diagnosis dispepsia yang dirujuk ke poli psikologi, melainkan juga penderita dengan gangguan fisik lain yang disinyalir berlatar belakang masalah psikologis (masalah ekonomi, masalah dengan pasangan, kenakalan remaja). Banyak pasien yang mengeluhkan adanya konflik dengan pasangan serta masalah ekonomi yang mendasari keluhan fisik mereka. Pasien yang dirujuk memiliki kecenderungan mengalami kecemasan, sehingga memunculkan keluhankeluhan dispepsia.

Kasus yang ditemukan peneliti di sebuah Puskesmas adalah seorang wanita berusia 28 tahun, telah menikah, mengeluhkan sering sekali merasa mual, perih di bagian perut, nyeri di bagian dada sehingga membuatnya sulit bernafas. Pasien mengungkapkan bahwa dirinya memiliki masalah dengan pasangan. Pasien mengeluhkan sikap pasangannya yang mulai berubah kasar beberapa tahun terakhir ini. Pasien sering terlibat pertengkaran dengan pasangan yang kamudian membuat pasien merasa cemas akan kelangsungan hidup rumah tangganya. Perasaan cemas tersebut semakin membuat pesien merasakan sakit terutama pada bagian dada dan perut. Pasien sendiri telah diperiksa oleh dokter dan menurut diagnosis dokter, pasien tersebut tidak mengalami gangguan pencernaan yang serius. Dokter berasumsi bahwa yang mendasari keluhan pasien adalah karena masalah psikologis, sehingga besar kemungkinan pasien tersebut mengalami dispepsia psikogenik.

Selain itu, para penderita dispepsia juga kurang memiliki keterampilan dalam beradaptasi dengan lingkungan sosialnya. Sebagian dari penderita dispepsia mengaku cemas ketika menghadapi masalah yang muncul di lingkungan sosialnya. Individu yang mengalami dispepsia cenderung mengurung diri di rumah bila individu tersebut mengalami masalah dan sering berpikiran buruk terhadap orang di sekitarnya.

Istilah dispepsia sendiri mulai gencar dikemukakan sejak akhir tahun 1980an, yang menggambarkan keluhan atau kumpulan gejala (sindrom) yang terdiri atas nyeri atau rasa tidak nyaman di epigastrium, mual, muntah, kembung, cepat kenyang, rasa penuh, sendawa, regurgitasi, dan rasa panas yang menjalar di dada (Djojodiningrat,2006).

Dispepsia adalah gangguan yang terjadi pada saluran pencernaan atas. Keluhan yang diutarakan meliputi nyeri ulu hati, pedih, mual yang disertai dengan muntah, rasa panas di dada dan perut, cepat merasa kenyang, kembung dan mulut terasa pahit karena banyaknya 
mengeluarkan gas asam (Hadi 1995). Seligman dan Rosenhan (Mulia, 2006) menyatakan bahwa gejala dispepsia biasanya diderita selama beberapa minggu atau bulan yang sifatnya episodik atau terus menerus. Penyebab munculnya gangguan ini beraneka ragam, salah satunya adalah pikiran dan perasaan pasien itu sendiri. Gangguan dispepsia yang disebabkan oleh masalah psikologis yang menimbulkan perasaan khawatir dan cemas pada penderitanya biasa disebut dengan dispepsia psikogenik.

Kecemasan adalah suatu keadaan emosional yang mempunyai ciri keterangsangan fisiologis, perasaan tegang yang tidak menyenangkan, dan perasaan aprehensif bahwa sesuatu yang buruk akan terjadi (Nevid dkk., 2005). Kecemasan timbul akibat adanya respons terhadap kondisi stres atau konflik. Konflik, baik yang datang dari luar maupun dalam diri sendiri, itu akan menimbulkan respons dari sistem saraf yang mengatur pelepasan hormon tertentu. Akibat pelepasan hormon tersebut, maka muncul perangsangan pada organ-organ seperti lambung, jantung, pembuluh darah maupun alat-alat gerak (Nevid dkk., 2005).

Kecemasan yang terus menerus dirasakan oleh penderita dispepsia akan meningkatkan aktivitas sistem saraf oto- nom dan sekresi hormon dari kelanjar endokrin. Keluhan pasien dispepsia yang banyak diutarakan antara lain nyeri ulu hati, perut perih, mual yang disertai rasa ingin muntah, rasa panas di dada dan perut, cepat kenyang, kembung, dan banyak mengeluarkan gas asam dari mulut. Gejala dispepsia psikogenik bila tidak ditangani dengan tuntas akan menjadi dispepsia organik.

Penanganan dispepsia saat ini lebih banyak dari sisi medis. Penanganan dispepsia psikogenik yang ditangani dengan medis biasanya hanya menyelesaikan keluhan fisik yang dirasakan bukan pada penyebab utama yang menimbulkan simtom-simtom dispepsia psikogenik (Mulia, 2006).

Penyebab utama yang lebih mengarah pada adanya kecemasan, diperlukan pendekatan secara psikologi dalam menangani penderita. Penanganannya lebih diarahkan untuk membantu penderita dalam mengatasi kecemasannya, sehingga tidak berada dalam kondisi yang penuh kecemasan dan kekhawatiran yang dapat mengganggu sistem fisiologis tubuh (Mulia, 2006).

Salah satu jenis psikoterapi untuk mengatasi kecemasan adalah relaksasi yang menggunakan teknik serangkaian gerakan tubuh yang bertujuan untuk melemaskan dan memberikan rasa 
nyaman pada seluruh tubuh (Corey, 2007). Relaksasi merupakan salah satu teknik pengelolaan diri yang didasarkan pada cara kerja sistem saraf simpatis dan parasimpatis. Ketika otot-otot sudah direlakskan akan menormalkan kembali fungsi-fungsi organ tubuh. Setelah seseorang melakukan relaksasi, dapat membantu tubuhnya menjadirelaks, sehingga dapat memperbaiki berbagai aspek kesehatan fisik. Relaksasi membantu individu untuk dapat mengontrol diri dan memfokuskan perhatian sehingga dapat mengambil respon yang tepat saat berada dalam situasi yang menegangkan (Subandi, 2002).

Beberapa penelitian menunjukkan efektivitas teknik relaksasi untuk mengurangi kecemasan pada berbagai macam subjek seperti ibu yang menyusui pertama kali, mahasiswi, penderita penyakit jantung, penderita migrain, penderita hipertensi, penderita stroke, ibu hamil pertama. Selain itu, relaksasi untuk menurunkan kecemasan pada penderita dispepsia juga telah terbuki keberhasilannya.

Relaksasi merupakan salah satu teknik dalam terapi perilaku.Relaksasi merupakan metode atau teknik yang digunakan untuk membantu manusia belajar mengurangi atau mengontrol reaktivitasfisiologis yang menimbulkan masalah bagi dirinya (McNeil \& Lawrence, 2002). Tujuan relaksasi adalah untuk mengurangi tingkat gejolak fisiologis individu dan membawa individu ke keadaan yang lebih tenang baik secara fisik maupun psikologis (Rout \& Rout, 2002). Namun, dalam penelitian Pargament, dkk. (1999) dijelaskan bahwa berdoa dan melakukan aktivitas penyembahan atau kegiatan agama lainnya lebih efektif dibandingkan dengan relaksasi otot progresif. Ungkapan ini menunjukkan bahwa menggunakan terapi relaksasi saja tanpa menambahkan aktivitas agama terbukti tidak cukup efektif membantu individu dalam kondisi sulit yang tidak terkontrol. Sebaliknya, penggunaan teknik yang sesuai dengan nilai yang dimiliki pasien akan memberikan hasil yang lebih baik (Hodge, 2008). Untuk itu, sangat diperlukan sebuah terapi yang disesuaikan dengan nilai-nilai yang dianut oleh masyarakat Indonesia, yakni dengan mengadaptasikan nilai-nilai keberagamaan yang dimiliki oleh klien.

Relaksasi sebagai salah satu teknik yang telah terbukti dapat mereduksi kecemasan pada berbagai subjek juga telah terbukti efektif mengurangi kecemasan pada penderita dispepsia (Mulia, 2006). Namun, hal yang selama ini belum pernah diteliti adalah penerapan teknik relaksasi untuk mengurangi 
kecemasan pada penderita dispepsia yang melibatkan unsur spiritualitas. Faktor spiritual adalah faktor penting yang juga memengaruhi proses penyembuhan dan intervensi psikologis. World Health Organization (WHO) pada tahun 1984 menyatakan bahwa kese-hatan manusia seutuhnya ditunjukkan oleh empat hal, yaitu sehat secara biologis, psikologis, sosial, dan spiritual (Hawari, 2005). Witmer dan Sweeney (Burke, Chauvin, \& Miranti, 2005) menyatakan bahwa elemen spiritual dalam diri manusia, mengintegrasikan dan mempersatukan elemen kebutuhan fisik, emosi, dan intelektual di dalam tubuh manusia dalam pertumbuhan dan perkembangannya. Selain itu, Prest dan Keller (Blume, 2006) menyatakan bahwa proses intervensi terhadap klien yang mempertimbangkan keyakinan agama yang dianut menjadi penting untuk menghindari resistensi apabila proses yang dilakukan dirasakan klien sebagai suatu hal yang berbeda dengan aturan agama yang diyakininya. Bagi umat Muslim, keimanan yang penting adalah percaya pada Allah dan Al-Quran sebagai sumber pengetahuan yang sempurna (Hasan, 2006).

Beberapa penelitian yang menggunakan terapi psikologis dan medis berbasis keislaman juga telah dilakukan, antara lain penelitian yang dilakukan oleh Saleh (2010) yang menjelaskan bahwa berzikir dapat menyehatkan saraf, penelitian Sholeh (2006) tentang terapi sholat tahajud untuk menyembuhkan berbagai penyakit, penelitian Trimulyaningsih (2009) tentang terapi kognitif perilaku religius untuk menangani depresi danpenelitian Purwanto (2006) tentang pelatihan relaksasi religiusitas untuk mengurangi insomnia. Penelitian-penelitian tersebut hasilnya membuktikan bahwa terapi psikologis berdasar keislaman dapat dilakukan untuk menyelesaikan masalah psikologis

Berdasarkan pemaparan di atas, dapat disimpulkan bahwa penanganan kecemasan adalah hal yang sangat penting. Relaksasi selama ini telah terbukti dapat mengurangi kecemasan. Berbagai metode relaksasi telah banyak dikembangkan seperti relaksasi progresif, relaksasi otot, relaksasi meditasi. Namun, pengembangan teknik relaksasi yang berkaitan dengan keyakinan seseorang (faith factor) belum dikaji secara mendalam apalagi yang mengarah pada keyakinan religi tertentu. Relaksasi dengan memasukkan unsur keyakinan dapat dilakukan oleh siapa saja yang yakin terhadap sesuatu dan dapat dipraktikkan oleh semua agama (Benson, 2000). Penelitian untuk mengetahui pengaruh 
relaksasi yang dikombinasikan dengan unsur spiritual dan religius dirasa perlu untuk semakin mengoptimalkan penanganan kecemasan khususnya pada penderita dispepsia.

Zikir merupakan bentuk dari unsur spiritual dan religiusitas. Zikir sebagai salah satu cara untuk mendekatkan diri pada Allah SWT dapat membantu individu membentuk persepsi yang lain selain ketakutan, yaitu keyakinan bahwa setiap stresor akan dapat dihadapi dengan baik dengan bantuan Allah. Umat Islam percaya bahwa penyebutan Allah secara berulang (zikir) dapat menyembuhkan jiwa dan menyembuhkan berbagai penyakit (Subandi, 2009). Saat seorang muslim membiasakan zikir, ia akan merasa dirinya dekat dengan Allah, berada dalam penjagaan dan lindungan-Nya, yang kemudian akan membangkitkan percaya diri, kekuatan, perasaan aman, tenteram, dan bahagia (Najati, 2005).

Kalimat zikir yang digunakan adalah kalimat Istigfar: Astagfirullahal 'azhiim (Saya mohon ampun kepada Allah yang maha Agung). Kalimat zikir tersebut diucapkan berulang-ulang dengan tujuan sebagai proses pembelajaran dan melatih untuk membangun daya juang dan kesungguhan demi meraih ridha, cinta dan perjumpaan dengan Allah SWT (AdzDzakiey, 2008).

Firman Allah SWT tentang membaca istigfar:

"Maka aku katakan kepada mereka : "mohon ampunlah (istigfar) kepada Tuhanmu, sesungguhnya Dia adalah Maha Pengampun, niscaya Dia akan memberikan hujan kepadamu dengan lebat, dan memperbanyak harta dan anak-anakmu dan mengadakan untukmu kebun-kebun dan mengadakan pula di dalamnya untukmu sungaisungai" (QS.Nuh: 10-12).

Sabda Rasulullah tentang kalimat istigfar:

"Barang siapa yang senantiasa beristigfar, maka Allah akan memberikan kegembiraan dari setiap kesedihannya dan kelapangan bagi setiap kesempitannya dan memberinya rizki dari arah yang tiada disangka-sangka" (HR. Abu Daud, Ibnu Majah dan Ahmad).

Berdasarkan teori-teori dan penelitian-penelitian yang telah diuraikan, maka hipotesis yang diajukan dalam penelitian ini adalah: Ada pengaruh pemberian relaksasi zikir terhadap penurunan tingkat kecemasan pada kelompok eksperimen dan kelompok kontrol penderita dyspepsia. 


\section{METODE PENELITIAN}

\section{Desain Penelitian}

Rancangan penelitian ini adalah kuasi eksperimen. Kuasi eksperimen merupakan penelitian eksperimen yang dilakukan tanpa randominasi, namun masih menggunakan kelompok kontrol. Penelitian ini menggunakan model perancangan prates dan pascates dengan menggunakan kelompok eksperimen dan kelompok kontrol dengan sampel yang ditetapkan secara non random (non randomized pretest posttes with control design) (Hadi, 2000).

\section{Subjek Penelitian}

Subjek dalam penelitian ini adalah orang-orang yang memiliki persyaratan sebagai berikut: (1) Diagnosis gangguan dispepsia dari dokter kemudian dirujuk ke bagian psikologi; (2) Laki-laki maupun perempuan berusia 20-60 tahun; (3) Beragama Islam; (4) Tidak sedang menjalani terapi psikologi kecuali terapi medis (obat) yang diberikan dokter; (5) Tingkat kecemasan berada dalam kategori sedang sampai dengan sangat tinggi dengan skor kecemasan antara 2156.

\section{Metode Pengumpulan Data}

Metode pengumpulan data yang digunakan dalam penelitian ini adalah dengan menggunakan skala untuk mengukur kecemasan. Skala kecemasan yang digunakan menggunakan Hamilton anxietas rating scale (HARS) yang terdiri atas 14 komponen (Hamilton, 1959) yaitu (1) Perasaan cemas, (2) Ketegangan, (3) Ketakutan, (4) Gangguan tidur, (5) Gangguan kecerdasan, (6) Perasaan depresi, (7) Gejala somatik, (8) Gejala sensorik, (9) Gejala kardiovaskuler, (10) Gejala pernapasan, (11) Gejala saluran pencernaan makanan, (12) Gejala urogenital, (13) Gejala vegetatif atau otonom, (14) Perilaku sewaktu wawancara.

Skala HARS pertama kali digunakan pada tahun 1959 yang diperkenalkan oleh Max Hamilton. HARS digunakan untuk mengukur tingkat kecemasan pada orang dewasa yang mengalami gangguan kecemasan khusunya kecemasan sesaat (state anxiety). HARS tidak digunakan untuk menegakkan diagnosis gangguan kecemasan yang lebih parah (misalnya, depresi, demensia, schizofen, histeria, obsesisif kompulsif). Skala HARS tidak dilakukan uji coba terlebih dahulu karena HARS telah terbukti memiliki validitas dan reliabilitas yang cukup tinggi yaitu 0,93 dan 0,97. Hal ini mengartikan bahwa skala HARS telah 
terbukti dapat mengukur tingkat kecemasan sesaat (state anxiety) secara valid.

Adapun cara penilaiannya adalah dengan sistem skoring, yaitu nilai 0 (tidak ada gejala), nilai 1 (gejala ringan, yaitu satu gejala dari pilihan yang ada), nilai 2 (gejala sedang, yaitu setengah dari gejala yang ada), nilai 3 (gejala berat, yaitu lebih dari setengah gejala yang ada), dan nilai 4 (gejala berat sekali, yaitu semua gejala ada).

Hasilnya kemudian dijumlah dengan kategorisasi sebagai berikut : skor kurang dari 14 berarti tidak ada kecemasan, skor 14 - 20 berarti kecemasan ringan, skor 21 - 27 berarti kecemasan sedang, skor 28 - 41 berarti kecemasan berat, dan skor 42 - 56 berarti kecemasan berat sekali.

\section{Prosedur Intervensi}

Secara umum, prosedur intervensi meliputi tahap persiapan penelitian dan tahap pelaksanaan. Tahap persiapan penelitian meliputi (a) Melakukan need assessment di lapangan, (b) Perizinan, (c) Penyusunan rancangan penelitian dan pembuatan modul terapi relaksasi zikir, (d) Seleksi terapis/fasilitator, (e) Persiapan fasilitator untuk melakukan pelatihan, $(\mathrm{f})$ Penentuan dan pencarian subjek penelitian, dan (g) Penandatanganan persetujuan subjek
Sementara tahap pelaksanaan meliputi prates, pascates, intervensi, dan tindaklanjut. Prates, pascates, dan tindak lanjut dilakukan dengan pemberian angket untuk diisi oleh subjek penelitian. Sementara itu intervensi yang diberikan berupa terapi relaksasi pernafasan dengan mengucapkan kalimat zikir dan doa. Intervensi dalam penelitian ini menggunakan metode seperti (a) Praktek atau latihan relaksasi zikir yang terdiri atas : relaksasi pernafasan dan zikir. Kalimat zikir yang digunakan dalam penelitian ini adalah dengan membaca Istigfar: Astagfirullahal'azhiim (Saya mohon ampun kepada Allah yang maha Agung). Membaca lafadh Baqiyaatush shalihat: Subhanallah.. wal hamdulillah.. wa la ilaaha illallah.. wallaahuakbar (Maha Suci Allah dan segala puji bagi Allah tiada Tuhan selain Allah dan Allah Maha Besar). (b) Dialog, ceramah dan tanya jawab : psikoedukasi tentang kecemasan, relaksasi dan zikir. (c) Diskusi, mengungkapkan pengalaman terapi: evaluasi pelaksanaan terapi relaksasi zikir yang terdiri atas relaksasi pernafasan dan zikir.

Proses pemberian intervensi akan lebih dijelaskan lebih lanjut dalam tabel dibawah ini : 
Tabel 1. Prosedur pemberian intervensi

\begin{tabular}{|c|c|c|c|c|}
\hline Hari ke & Sesi & Waktu & Kegiatan & Tujuan \\
\hline \multirow[t]{6}{*}{ Satu } & 1 & 5 menit & $\begin{array}{l}\text { Perkenalan } \\
\text { - Self } \\
\quad \text { presentation }\end{array}$ & $\begin{array}{l}\text { Membangun hubungan yang baik dan } \\
\text { kerjasama antar peserta dan terapis } \\
\text { serta peserta dengan peserta. }\end{array}$ \\
\hline & 2 & 5 menit & $\begin{array}{l}\text { pengisian lembar } \\
\text { inform consent }\end{array}$ & $\begin{array}{l}\text { Memperjelas waktu, kontrak yang akan } \\
\text { dilakukan selama } 3 \text { kali pertemuan } \\
\text { yang harus diikuti oleh peserta dan } \\
\text { ketentuan main dalam terapi. }\end{array}$ \\
\hline & 3 & $\begin{array}{l}20 \\
\text { menit }\end{array}$ & $\begin{array}{l}\text { Psikoedukasi : } \\
\text { - Kecemasan, } \\
\text { relaksasi dan } \\
\text { zikir. }\end{array}$ & $\begin{array}{l}\text { Memberi informasi pada peserta } \\
\text { mengenai kecemasan, relaksasi dan } \\
\text { zikir (pengertian, manfaat, macam- } \\
\text { macam relaksasi, dampak relaksasi, } \\
\text { dll. }\end{array}$ \\
\hline & 4 & $\begin{array}{l}10 \\
\text { menit }\end{array}$ & Brain storming & $\begin{array}{l}\text { membuat kumpulan pendapat, infor- } \\
\text { masi, pengalaman semua peserta. }\end{array}$ \\
\hline & 5 & $\begin{array}{l}30 \\
\text { menit }\end{array}$ & $\begin{array}{l}\text { relaksasi } \\
\text { pernafasan disertai } \\
\text { zikir }\end{array}$ & $\begin{array}{l}\text { untuk menimbulkan rasa aman, menu- } \\
\text { runkan kegelisahan dan menambah } \\
\text { keimanan }\end{array}$ \\
\hline & 6 & 5 menit & pekerjaan rumah & $\begin{array}{l}\text { untuk memonitoring pesarta dalam } \\
\text { melakukan relaksasi pernafasan. }\end{array}$ \\
\hline \multirow[t]{5}{*}{ II } & 1 & $\begin{array}{l}10 \\
\text { menit }\end{array}$ & $\begin{array}{l}\text { Self presentation } \\
\text { tugas rumah }\end{array}$ & $\begin{array}{l}\text { Mengetahui pengaruh tugas rumah } \\
\text { terhadap kondisi peserta. }\end{array}$ \\
\hline & 2 & $\begin{array}{l}30 \\
\text { menit }\end{array}$ & $\begin{array}{l}\text { pengulangan } \\
\text { tahap-tahap } \\
\text { relaksasi zikir }\end{array}$ & $\begin{array}{l}\text { Mengingat kembali teknik-tekbik yang } \\
\text { telah diberikan selama terapi. }\end{array}$ \\
\hline & 3 & $\begin{array}{l}10 \\
\text { menit }\end{array}$ & $\begin{array}{l}\text { evaluasi metode: } \\
\text { - } \quad \text { Self } \\
\quad \text { presentation } \\
\text { - } \quad \text { Sharing }\end{array}$ & $\begin{array}{l}\text { Untuk melihat ada tidaknya perubahan } \\
\text { atau kemajuan yang dialami peserta } \\
\text { setelah menjalani keseluruhan sesi } \\
\text { terapi. }\end{array}$ \\
\hline & 4 & 5 menit & $\begin{array}{l}\text { pemberian } \\
\text { pascates }\end{array}$ & $\begin{array}{l}\text { Untuk mengukur kembali kondisi } \\
\text { peserta setelah diberikan terapi. }\end{array}$ \\
\hline & 5 & 5 menit & terminasi & $\begin{array}{l}\text { Untuk mengakhiri terapi dan } \\
\text { memberikan penekanan kepada } \\
\text { peserta bahwa proses terapi tidak } \\
\text { hanya berhenti sampai disini namun } \\
\text { harus terus dilaih sendiri dirumah. }\end{array}$ \\
\hline
\end{tabular}


Teknik Analisis Data

Data dianalisis menggunakan teknik statistik perangkat lunak Statistical Product and Service Solution (SPSS) for windows 16.0.Analisis untuk menguji hipotesis dalam penelitian ini menggunakan Mann Whitney U.

\section{HASIL PENELITIAN}

\section{Deskripsi Data Penelitian}

Subjek penelitian eksperimen terdiri atas 4 orang yang berjenis kelamin laki-laki dan perempuan.

Tabel 2. Deskripsi kecemasan subjek kelompok eksperimen

\begin{tabular}{cccccc}
\hline Subjek & $\begin{array}{c}\text { jenis } \\
\text { kelamin }\end{array}$ & usia & skor prates & $\begin{array}{c}\text { skor } \\
\text { pascates }\end{array}$ & $\begin{array}{c}\text { skor } \\
\text { gained }\end{array}$ \\
\hline Ss & Perempuan & 51 th & 29 (berat) & 15 (ringan) & 14 \\
Mj & laki-laki & 42 th & 23 (sedang) & 14 (ringan) & 9 \\
is & Perempuan & 38 th & 36 (berat) & 16 (ringan) & 20 \\
mw & Perempuan & 60 th & 30 (berat) & 8 (ringan) & 22 \\
\hline
\end{tabular}

Tabel 3. Deskripsi kecemasan subjek kelompok kontrol

\begin{tabular}{cccccc}
\hline subjek & $\begin{array}{c}\text { jenis } \\
\text { kelamin }\end{array}$ & usia & skor prates & $\begin{array}{c}\text { skor } \\
\text { pascates }\end{array}$ & $\begin{array}{c}\text { skor } \\
\text { gained }\end{array}$ \\
\hline sg & laki-laki & 59 th & 33 (berat) & 30 (berat) & 3 \\
pr & perempuan & 52 th & 26 (sedang) & 23 (sedang) & 3 \\
as & perempuan & 36 th & 34 (berat) & 26 (sedang) & 8 \\
aw & perempuan & 38 th & 38 (berat) & 27 (sedang) & 11 \\
\hline
\end{tabular}

Tabel 4. Deskripsi statistik perbandingan prates dan pascates kelompok eksperimen dan kelompok kontrol

\begin{tabular}{ccccccccc}
\hline klasifikasi & \multicolumn{4}{c}{ kelompok eksperimen } & \multicolumn{3}{c}{ kelompok control } \\
\cline { 2 - 9 } & min & maks & rerata & SD & min & maks & rerata & SD \\
\hline prates & 23 & 36 & 29,50 & 5,322 & 26 & 38 & 32,75 & 4,991 \\
pascates & 8 & 16 & 13,25 & 3,593 & 23 & 30 & 26,50 & 2,886 \\
\hline
\end{tabular}




\section{Hasil Uji Hipotesis}

Data uji Mann Whiteny $U$ prates dan pascates antara kelompok ekperimen dan kelompok control

Tabel 5. Hasil Test Statistics ${ }^{\mathrm{a}}$

\begin{tabular}{lrr}
\hline & \multicolumn{1}{c}{ prates } & \multicolumn{1}{c}{ pascates } \\
\hline Mann-Whitney U & 5,000 &, 000 \\
Wilcoxon W & 15,000 & 10,000 \\
Z &,- 866 & $-2,309$ \\
Asymp. Sig. (2-tailed) &, 386 &, 021 \\
Exact Sig. [2*(1-tailed Sig.)] &, $486^{\mathrm{b}}$ &, $029^{\mathrm{b}}$ \\
\hline
\end{tabular}

a. Grouping Variable: kelompok

b. Not corrected for ties.

Berdasarkan analisis di atas, saat prates terlihat tidak ada perbedaan tingkat kecemasan antara kedua kelompok. Hal ini ditunjukkan dengan nilai $\mathrm{p}=$ 0,386; p $>0,05$ (tidak signifikan). Sedangkan pada saat pascates terlihat ada perbedaan tingkat kecemasan yang singnifikan antara kedua kelompok. Hal ini ditunjukkan dengan nilai $p=0,021$; $p<0,05$ (signifikan). Dari hasil analisis uji hipotesis ini dapat disimpulkan bahwa ada perbedaan tingkat kecemasan antara kelompok eksperimen dan kelompok kontrol.

\section{Hasil Analisis Kualitatif}

Secara keseluruhan, hasil penelitian ini menunjukkan bahwa terapi relaksasi zikir dapat menurunkan tingkat kece- masan yang alami oleh penderita dispepsia. Hal tersebut dapat dilihat dari perbedaan skor kecemasan ketika sebelum diberikan perlakuan dan sesudah diberikan perlakuan. Terdapat hal-hal yang mendukung keberhasilan terapi, yaitu semangat subjek dalam mengikuti terapi serta kooperatif sehingga muncul suasana yang nyaman dan keterbukaan.

\section{PEMBAHASAN}

Tujuan utama penelitian ini adalah untuk mengetahui pengaruh terapi relaksasi zikir dalam menurunkan tingkat kecemasan pada pasien dispepsia. Berdasarkan hasil analisis data, diketahui bahwa terdapat perbedaan tingkat kecemasan antara kelompok eksperimen 
yang diberi perlakuan relaksasi zikir dengan kelompok kontrol yang tidak diberi perlakuan. Pada kelompok eksperimen yang diberi perlakuan terapi relaksasi zikir terjadi penurunan tingkat kecemasan lebih banyak dibandingkan dengan kelompok kontrol yang tidak diberi perlakuan.

Data tingkat kecemasan pada kelompok eksperimen menunjukkan rerata prates $=29,50$ dan pascates $=$ 13,25 . Hal ini menunjukkan bahwa ada penurunan tingkat kecemasan yang signifikan dari prates (sebelum perlakuan) ke pascates (setelah perlakuan) pada kelompok eksperimen. Penurunan nilai rerata prates dan pascates kelompok eksperimen sebesar 16,25.

Data pada kelompok kontrol menunjukkan perubahan tingkat kecemasan namun nilainya tidak sebesar dibandingkan kelompok eksperimen. Data tingkat kecemasan pada kelompok kontrol menunjukkan rerata prates $=$ 32,75 dan pascates $=26,50$. Penurunan nilai retata prates dan pascates kelompok konrol sebesar 6,25. Hal ini menunjukkan bahwa tidak ada penurunan tingkat kecemasan yang signifikan dari prates ke pascates pada kelompok kontrol.

Hasil dari penelitian ini menunjukkan bahwa terapi relaksasi zikir dapat menurunkan tingkat kecemasan pada pasien dispepsia. Hasil uji beda Mann Whitney $U$ menunjukkan bahwa ada perbedaan tingkat kecemasan antara kelompok eksperimen dan kelompok kontrol pada saat pascates. Hal ini ditunjukkan dari nilai $\mathrm{p}<0,05$ yang berarti signifikan. Nilai prates tampak tidak ada perbedaan tingkat kecemasan antar kedua kelompok $(p=0,386 ; p>$ 0,05 yang berarti tidak signifikan), karena tingkat kecemasan antara kelompok eksperimen dan kelompok kontrol samasama tinggi. Namun berbeda dengan nilai pascates yang tampak ada perbedaan tingkat kecemasan yang signifikan antar kedua kelompok $(p=0,021$; $p<0,05$ yang berarti signifikan).

Hasil penelitian menunjukkan adanya penurunan tingkat kecemasan yang signifikan pada kelompok eksperimen pada saat sebelum dan setelah diberikan terapi relaksasi zikir. Hal ini disebabkan oleh kesungguhan, semangat dan kooperatif para subjek ketika mengikuti terapi relaksasi zikir. Adanya penurunan tingkat kecemasan para subjek juga dipengaruhi oleh isi materi yang diberikan berdasarkan tahapan-tahapan yang saling berkaitan, sehingga selama proses terapi subjek merasakan langsung manfaat dari setiap tahap pelaksanaan program terapi. Halhal baik yang dirasakan subjek dari tiap- 
tiap tahap pelaksanaan terapi membuat subjek memahami manfaat langsung program terapi ini.

Penelitian ini sejalan dengan penelitian yang dilakukan oleh Benson (2000) bahwa respon relaksasi yang melibatkan keyakinan yang dianut akan mempercepat terjadinya keadaan rileks. Dengan kata lain, kombinasi respons relaksasi dengan melibatkan keyakinan akan melipatgandakan manfaat yang didapat dari respon relaksasi itu sendiri. Sungkan (Purwanto, 2006), zikir sebagai salah satu bentuk ibadah dalam agama Islam merupakan relaksasi religius, dengan mengucapkan lafadz Alloh secara terus menerus dengan pelan dan ritmis akan dapat menimbulkan respon relaksasi. Pengulangan lafadz tersebut disertai keyakinan terhadap kasih sayang-Nya, perlindungan-Nya dan sifat-sifat baik-Nya yang lain akan menimbulkan rasa tenang dan aman.

Pasien dispepsia memperoleh manfaat langsung, seperti rasa nyeri berkurang, badan terasa lebih santai, otototot kendor, tidur lebih berkualitas, nafsu makan meningkat, tidak mudah tersinggung, mengelola emosi dengan baik, pikiran lebih tenang, pusing berkurang dan bersemangat. Hal ini seperti yang diungkapkan McNeil dan Lawrence (2002) bahwa relaksasi merupakan metode atau teknik yang digunakan untuk membantu manusia belajar mengurangi atau mengontrol reaktivitas fisiologis yang menimbulkan masalah bagi dirinya.Tujuan relaksasi adalah untuk mengurangi tingkat gejolak fisiologis individu dan membawa individu ke keadaan yang lebih tenang, baik secara fisik maupun psikologis.

Zikir membantu individu membentuk persepsi yang lain selain ketakutan, yaitu keyakinan bahwa semua konflik akan dapat dihadapi dengan baik dengan bantuan Alloh SWT. Saat seorang membiasakan berzikir, ia akan merasa dirinya dekat dengan Alloh SWT, berada dalam lindungan-Nya yang kemudian akan membangkitkan percaya diri, kekuatan, perasaan aman, tentram dan bahagia (Najati, 2005). Secara biopsikologi, zikir akan membuat seseorang merasa tenang sehingga menekan kerja sistem syaraf simpatetis dan mengaktifkan kerja syaraf parasimpatetis (Saleh, 2010).

Penelitian ini tidak luput dari keterbatasan, diantaranya adalah peneliti ridak melakukan secara mandiri pemantauan saat peserta diberikan tugas rumah, peneliti tidak melakukan pengukuran lebih lanjut (follow up) setelah proses terapi sehingga tidak dapat melihat efektivitas terapi ini. Peserta yang menjadi subjek dalam penelitian ini 
kurang dapat menggeneralisasi karena subjek yang hanya 4 orang.

\section{SIMPULAN DAN SARAN}

\section{Simpulan}

Berdasarkan hasil penelitian yang telah dilakukan, maka dapat disimpulkan bahwa terapi relaksasi zikir dapat menurunkan tingkat kecemasan pada penderita dyspepsia.

\section{Saran}

Adapun saran untuk penelitian selanjutnya yaitu sebagai berikut: (1) Melihat efektivitas dari relaksasi zikir pada pasien dispepsia, pasien dispepsia diharapkan bisa terus melakukan relaksasi zikir sebagai upaya pengobatan; (2) Pihak puskesmas dapat memberikan terapi relaksasi zikir ini dalam bentuk kelompok atau individu agar pasien lain yang tidak termasuk dalam subjek penelitian ini dapat memperolah manfaat dari relaksasi zikir ini; (3) Peneliti selanjutnya dapat menggunakan terapi relaksasi zikir untuk meneliti aspek psikologis lain pada penderita dyspepsia; (4) Peneliti selanjutnya lebih memperhatikan jumlah subjek penelitian agar penelitian dapat digenaralisasi.

\section{DAFTAR PUSTAKA}

Adz-Dzakiey, H.B. (2008). Prophetic Intelligence; kecerdasan Kenabian. Yogyakarta : Penerbit Al Manar.

Anggraeni. W. N. (2014). Pengaruh Terapi Relaksasi Dzikir untuk Menurunkan Stres pada Penderita Hipertensi Esensial. Tesis. Yogyakarta : Fakultas Psikologi Dan IImu Sosial Budaya UII.

Aro P., Talley N.J., Ronkainen J., Storskrubb T., Vieth M., Johansson S.E., et al. (2009). Anxiety is Associated with Uninvestigated and Functional Dyspepsia (Rome III criteria) in a Swedish population-based study. Gastroenterology 137: 94-100.

Ash-Shiddieqy, T. M. H. (2001). Al-Islam Jilid 1. Semarang: PT. Pustaka Rizki Putra.

Alkinson, R.L. (1999). Pengantar Psikologi: Jilid 2, terjemahan-edisi kedeIapan. Batam Centre: Interaksa.

Barlow, D. H. (2002). Anxiety and Its Disorders: The Nature and Treatment of Anxiety and Panic, Second Edition. New York: The Guilford Press. 
Benson, R. (2000). Keimanan Yang Menyembuhkan : Dasar-Dasar Respons Relaksasi (terjemahan). Bandung: Kaifa.

Blackburn, I. M., \& Davidson, K. (1994). Terapi Kognitif untuk Depresi dan Kecemasan: suatu petunjuk bagi prakisi, terjemahan. Semarang: IKIP Semarang Press.

Carson. Robert C., Butcher, James N. (1992). Abnormal Psychology and Modern Life. Ninth Edition. New York: Harpercollins Publisher.

Corey, G. (2007). Teori dan Praktek Konseling \& Psikoterapi. Bandung: PT Refika Aditama.

Davis, M., Eshelman, E. R., \& McKay, M. (1995). Panduan Relaksasi dan Reduksi Stres (Terjemahan), Edisi III. Jakarta: Penerbit Buku Kedokteran EGC.

Djojodiningrat D. (2006). Buku ajar ilmu penyakit dalam. Edisi ke-4. Jakarta: Pusat Penerbitan Departemen Ilmu Penyakit Dalam Fakultas Kedokteran Universitas Indonesia.

Durand, V. M. \& Barlow, D H. 2003. Essentials of Abnormal Psychology. Pacific Grove: Wadsworth Thomson Learning.
Hadi, S. (1995). Gastroenterologi, Edisi ke-6. PT. Alumni: Bandung.

Hadi, S. (2000). Metodologi Research 4. Yogyakarta : Penerbit Andi.

Halgin, R. P. \& Whitbourne, S. K. (2005). Abnormal Psychology: Clinical Perspective on Psychological Disorders. Fourth Edition. New York: McGraw Hill Companies, Inc.

Hamilton, M. (1959). The Assesment of Anxiety States by Rating. British Journal of Medical Psychology. 32. 50-55.

Hasan, A. B. B. P. (2006). Psikologi Perkembangan Islami. Jakarta: PT. Raja Grafindo Persada.

Hawari, D. (2005). Dimensi Religi dalam Praktek Psikiatri dan Psikologi. Jakarta : Fakultas Kedokteran Universitas Indonesia.

Hodge, D.R. (2008). Moving Toward Culturally Competent Practice with Muslims: Modifying Cognitive Therapy with Islamic Tenets. Social Work, 53, (1), 3141.

Kalat, J. W. (2007). Biological Psychology. California: Thomson Learning, Inc. 
Kartono. (2007). Psikologi Wanita 2, Mengenal Wanita sebagai Ibu dan Nenek. Bandung: Mandar Maju.

Khairiyah. U. (2013). Pengaruh Terap Dzikir Untuk Menurunkan Stres Pada Penderita Low Back Pain. Tesis. Yogyakarta : Fakultas Psikologi Dan Ilmu Sosial Budaya UII.

Kirsner. (1994). The Growth of Gastroenterologic Knowledge Durung the Twentieth Century. Lea \&Febiger : A Waverly Company.

Kusuma, N. H. S., Arinton, I. G., Paramita, H. (2011). Korelasi Skor Dispepsia dan Skor Kecemasan pada Pasien Dispepsia Rawat Jalan Klinik Penyakit Dalam Di RSUD Prof. Dr. Margono Soekarjo Purwokerto. Mandala of Health, volume 5, Nomor 3, September 2011.

Maimunah, A. (2011). Pengaruh Pelatihan Relaksasi dengan Dzikir untuk Mengatasi Kecemasan Pada Ibu Hamil Pertama. Psikoislamika, Vol. 8, No. 1, Hal. 1-22.

McNeil, D.W. \& Lawrence, S. M. (2002). Relaxation Training. Ensyclopedia of Psychotherapy. American Psyciatric Association.
Mulia, E. B. (2006). Pengaruh Progressive Muscle Relaxation terhadap Taraf Kecemasan Sesaat dan Frekuensi Munculnya Gejala Penyakit pada Penderita Dispepsia Psikogenik. Jurnal Psikologi. Vol. 18, No. 2. Hal. 15-34.

Najati, M. U. (2005). Al-Qur'an dan Psikologi (Terjemahan). Jakarta: Aras Pustaka.

Nevid, J., Rathus, S., \& Greene, B. (2005). Psikologi Abnormal, Edisi ke-5, Jilid 1. Erlangga: Jakarta.

Ormrod, S. E. (2004). Human Learning: $4^{\text {th }}$ edition. New Jersey: Pearson Education, Inc.

Pargament, dkk. (1999). The vigil : Religion And The Search For Control In The Hospital Waiting Room. Journal of Health Psychology, 4, (3), 327-341.

Pinel, J. P. J. (2009). Biopsikologi. Edisi Ketujuh (Terjemahan). Yogyakarta: Pustaka Pelajar.

Purwanto, S. (2006). Pengaruh Pelatihan Relaksasi Religius Untuk Mengurangi Gangguan Insomnia. Tesis (tidak diterbitkan). Yogyakarta: Fakultas Psikologi Universitas Gagjah Mada. 
Rathus, S. A., \& Nevid, J. S. (1991). Abnormal Psychology. New Jersey: Prentice Hall.

Rout, U. R., \& Rout, J.K. (2002). Stress Management for Primary Health Care Profesional. New York : Kluwer Academic Publisher.

Sadif. R. S. (2013). Pengaruh Terapi Relaksasi Dzikir Untuk Menurunkan Tingkat Stres Pada Penderita Gagal Ginjal Yang Menjalani Haemodialisa. Tesis. Yogyakarta : Fakultas Psikologi Dan Ilmu Sosial Budaya UII.

Saleh, A. Y. (2010). Berdzikir untuk Kesehatan Syaraf. Jakarta: Penerbit Zaman.

Sarafino, E. P. (1998). Health Psychology. Third Edition. Danver: John Willey and Sons.

Sholeh, M. (2006). Terapi Sholat Tahajjud : Menyembuhkan Berbagai
Penyakit. Jakarta: Hikmah, PT. Mizan Publika.

Stuart and Sundeen. (1998). Buku Keperawatan (alih bahasa) Edisi 3. Jakarta: EGC.

Subandi. (2002). Psikoterapi. Yogyakarta: UGM.

Subandi, M. A. (2009). Psikologi Dzikir. Yogyakarta: Pustaka Pelajar.

Suyamto., Prabandari, Y. S., \& Marchira, C. M. (2009). Pengaruh Relaksasi Otot dalam Menurunkan Skor Kecemasan T-TMAS Mahasiswa Menjelang Ujian Akhir Program Di Akademi Keperawatan Notokusumo Yogyakarta. Berita Kedokteran Masyarakat, 25 (3) 142149.

Trimulyaningsih, N. (2009). Terapi Kognitif Perilakuan Religius untuk Menangani Depresi. Tesis. Yogyakarta: Fakultas Psikologi Universitas Gadjah Mada. 